\title{
PENERAPAN SISTEM TEKNOLOGI PADA PENDIDIKAN DI ERA NEW NORMAL
}

\author{
Niliyani \\ Program Studi Pendidikan IPS, FKIP Universitas Lambung Mangkurat \\ Email: Niliyaninely@gmail.com
}

\begin{abstract}
ABSTRAK
Akhir-akhir ini Indoneisa bahkan dunia dihebohkan terhadap virus yang muncul untuk pertama kali dalam peradaban manusia, yang mana virus tersebut menyerang sistem kekebalan tubuh yang ada di dalam tubuh, tidak hanya lansia, anak muda, anak-anak bahkan bayi pun dapat terkena virus tersebut. Virus yang dinamakan Covid 19 muncul pertama kali di Cina tepatnya di daerah Wuhan dan bereaksi dengan cepat menularkannya kepada manusia. Indonesia kala itu bersikap santai dengan keadaan pelik di negara lain, hingga terjadilah satu diantara warga negara Indonesia terkena virus tersebut, Indonesia yang awalnya santai dan terkesan acuh berubah menjadi peduli karena lonjakan masyarakat yang terenfeksi virus tersebut. Pemerintah terpaksa menghentikan sementara seluruh masyarakatnya untuk beraktivitas diluar rumah demi menghindari penyebaran virus tersebut, mulai dari bekerja bahkan pendidikan dialih sistemkan dengan model baru mengaitkan segala teknologi. Sistem yang dikatakan banyak yang kesusahan terlebih untuk kalangan menengah kebawah, namun dikabarkan setelah dicetuskan pemerintah mengenai kehidupan New Normal, pendidikan pun ikut andil boleh dilangsungkan secara tatap muka, jika keadaan daerah tersebut sudah berada di zona hijau dan mampu menerapkan protokol kesehatan.
\end{abstract}

Kata kunci: Pendidikan, Teknologi, Sistem,

New Normal

\section{PENDAHULUAN}

Keadaan Covid 19 membuat pemerintah harus mengambil kebijakan yang berat, setelah covid 19 mulai masuk ke Indonesia segala aktivitas yang dilakukan diluar rumah mulai dihentikan sejalan dengan melonjaknya pasien positif covid 19, dari semua instansi, tempat bekerja, cafe, pendidikan. Semua terpaksa sementara dirumahkan, namun kejadian tersebut tidak bisa hanya dilakukan dengan berdiam diri. Dengan tidak bisanya aktivitas dilakukan diluar rumah, penerapan sistem baru pun harus dilakukan dan diterapkan. Teknologi yang berperan penting dari hikmah 
kejadian ini, semua yang dilakukan mulai dari kerjaan, tempat makan bahkan pendidikan, sangat dibantu dengan keahlian teknologi. Khususnya pendidikan, Pendidikan dalam harapan dunia harus mampu mempersiapkan peserta didik menjadi makhluk yang global dan bisa bertanggung jawab dan mampu menjadi satu diantara yang bisa membawa perubahan (change) dalam memerangi ketidakadilan sebagai dampak negatif globalisasi. (Subiyakto, B., \& Mutiani, M. 2019). Dampak negatif dari dunia sekarang harus bisa membuat peserta didik, tenaga pendidik maupun masyarakat pintar dan mampu mempersiapkan dan melaksanakan sistem baru untuk menunjang proses pendidikan. Dengan adanya kemajuan teknologi menghadapkan masyarakat Indonesia kepada dampak globalisasi yang terjadi dan kaitannya terhadap perkembangan ipteks, serta pergeseran nilai. Kejadian ini hadir di tengah realita lingkungan kehidupan, permasalahan atau kerumitan sosial. (Subiyakto, B., \& Mutiani, M. 2019).

\section{PEMBAHASAN}

Pendidikan merupakan sesuatu yang tidak bisa lepas dari insan manusia sejak manusia itu lahir, hak-hak yang dimiliki oleh seluruh manusia satu diantaranya iyalah mendapatkan pendidikan yang layak. Pendidikan dini telah diterima seluruh manusia yang bernafas dari pendidikan yang dilakukan keluarga, terutama orang tua, lingkungan keluarga menjadi faktor utama yang memberikan pendidikan kepada anak hingga iya berkembang menjadi dewasa dan menjadi penyalur pendidikan tersebut terhadap orang lain. Tanpa disadari orang tua telah menjalurkan didikan terhadap anaknya, itulah mengapa sering dikatakan sekolah pertama iyalah lingkungan keluarga, baik-buruknya anak ialah bagaimana didikan yang dilakukan keluarga terutama orang tua, dari faktor aturan yang dilakukan, kewajiban membuat kedisiplinan sang anak sudah dibiasakan sedari kecil mengenai aturan ataupun kewajiban yang dicetuskan oleh keluarga terutama orang tua. Mulai dari memberikan pengetahuan mengenai semua hal yang negatif maupun positif dan dampak yang terjadi jika ia melakukan hal-hal tersebut dan dampak yang terjadi terhadap orang lain.

Pendidikan adalah hal yang berguna untuk meningkatkan sumber daya manusia. Sampai sekarang pendidikan terus diperbaiki dari segala komponen. Hal tersebut tentunya tidak terlepas dari perilaku atau sikap individu yang 
dipengaruhi oleh pendidikan. Perkembangan jaman tidak hanya memiliki dampak positif, tetapi juga dampak negatif. tercermin dari keadaan sekarang jika dilihat dari sudut pandang positif yang terjadi, perilaku anak yang suka memainkan tenologi seperti handphone merupakan dampak yang baik jika dikaitkan dengan pendemi yang terjadi sekarang, bayangkan jika anak yang buta akan teknologi, tidak bisa memainkan handphonenya, maka pada saat pendemi sekarang tentunya akan sangat menyusahkan, yang mana anak yang lain sudah lancar dan ia masih belajar. Hal tersebut pasti juga merugikan peserta didik yang lainnya, otomatis pembelajaran akan lambat karena harus mengajarkan berulang kali kepada anak yang gagap tekonologi. (Wahyuningsih, S., Abbas, E. W., \& Mutiani, M. 2020).

Gambaran kehidupan suatu masyarakat Indonesia dalam keseharian sangat rumit dan sulit dipahami. Hal tersebut ditunjukkan seiring dengan munculnya permasalahan sosial yang terjadi terhadap suatu masyarakat. Pola sikap masyarakat menggambarkan hadirnya perilaku dan sikap kurang baik khususnya di lingkup pendidikan. (Mutiani, M. 2019). Kehidupan dunia akan terus berkembang tidak akan bisa dihentikan ataupun dipercepat, dan mau tidak mau seluruh umat manusia termasuk peserta didik mau tidak mau harus menerima kenyataan permasalahan pelik yang terjadi.

Dengan dampak sekarang yang terjadi pada peserta didik, tenaga pendidik maupun masyarakat tanpa sadar ikut andil dalam mengamati kehidupan lingkungan tentang perkembangan permasalahan sehingga bersifat kontekstual. Segala aktivitas belajar peserta didik sekarang tidak hanya menyentuh aspek kognitif, tetapi juga belajar mengaitkan pembelajaran teknologi dengan permasalahan global yang sekarang terjadi baik dari persfektif psikologis (humanistik). (Syaharuddin, S., \& Mutiani, M. 2020).

Suksesnya suatu pembelajaran dapat diklasifikasikan dari berbagai aspek yang saling berinteraksi. Dari aspek pembelajaran, di antaranya tenaga pendidik, peserta didik, tujuan yang diharapkan, materi, metode, dan strategi pembelajaran, dari semua aspek tersebut harus saling berinteraksi dan menimbulkan adanya 
timbal balik yang terjadi dalam pembelajaran. (Rahman, A. M., Mutiani, M., \& Putra, M. A. H. 2019). Seluruh mata pelajaran pada setiap jenjang, dari pendidikan dasar dan menengah pertama dan tingkat atas adalah sifat terpadu (integrated), dengan harapan supaya mata pelajaran yang diajarkan lebih bermakna bagi peserta didik sehingga pengorganisasian materi/bahan pelajaran mampu disesuaikan dengan lingkungan, karakteristik, dan kebutuhan siswa pada saat pendemi ini. (ABBAS, E. W., Hidayat Putra, M. A., \& Noor Handy, M. R. 2019).

Kualitas kegiatan pembelajaran yang ada di sekolah dipengaruhi banyak faktor. Faktor tersebut bisa dilihat dari tenaga pendidik (guru), peserta didik, sarana dan prasarana, lingkungan, dan aturan yang berlaku, pendemi yang terjadi telah mengubah pola pembelajaran menjadi sistem baru dengan teknologi yang dapat membantu kegiatan suatu pendidikan yaitu pembelajaran dengan kualitas tinggi dengan sistem yang tentunya berbeda seperti dilakukan dilingkungan sekolah. (Mutiani, M., WARMANSYAH ABBAS, E. R. S. I. S., Syaharuddin, S., \& Susanto, H. 2019).

Kemajuan suatu bangsa dapat dinilai dari bagaimana penyelenggaraan dan pelayanan pendidikan terhadap rakyatnya di suatu bangsa. Seperti kita ketahui di Indonesia pendidikan diterapkan dalam program pembelajaran wajib (Wajar) 12 tahun, dari SD, SLTP, SLTA. (Hasanah, M., \& Mutiani, M. 2019). Adanya keinginan dan tekad bersama merupakan syarat mutlak timbulnya sebuah rasa cinta terhadap tanah air, Indonesia yang mempunyai berbagai suku bangsa, daerah, dan ribuan pulau bukanlah menjadi sebuah hambatan untuk menjadi sebuah bangsa yang aktif dalam pemecahan masalah karena adanaya kemauan dan tekad untuk hidup bersama. (Nasih, M., Abbas,E. W., \& Syaharuddin, S. 2019).

Dengan pendemi sekarang sistem pembelajaran baru seperti daring diterapkan untuk mengatasi sistem pembelajaran yang harus tetap berjalan, namun umumnya apapun yang dilakukan pemerintah pasti menuai adanya pro dan kontra, karena tidak sedikit masyarakat yang peserta didiknya berada di daerah-daerah yang susah untuk masalah terhubung ke jejaring internet atau susah sinyal, belum lagi banyaknya peserta didik yang keluarganya tidak mampu 
mewujudkan hadirnya teknologi canggih untuk membantu proses pembelajaran sang anak.

Pada umumnya masyarakat mempunyai kebudayaan. Setiap kebudayaan merupakan suatu sistem pengetahuan yang meliputi sistem idea tau gagasan yang ada dalam pola pikir manusia, kebiasaan yang terus menerus dilakukam sehingga dalam kehidupan sehari-hari kebudayaan itu bersifat abstrak. Nah, sistem pendidikan yang dilakukan di daerah-daerah pelosok yang kebiasaannya sangat jarang menggunakan teknologi membuat masyarakat, peserta didik dan lingkungannya sudah membudaya dengan keadaan yang ada, sehingga masyarakat terkesan rancu dan bingung dengan sistem pembelajaran yang dilakukan pemerintah. (Subiyakto, B., Mutiani, M., \& Hidayat Putra, M. A. 2019).

Kebiasaan yang sudah membudaya mengharuskan masyarakat mempunyai kemampuan untuk dapat saling bekerjasama dalam menjalankan sistem baru dengan keaadaan yang terjadi, dan hal tersebut tidak dapat terlepas dari adanya peran sosial yang mereka miliki. Hakikat peran sosial ialah kaitan sosial yang terjalin dalam kehidupan sehari-hari antar warga masyarakat. (Mutiani, M., Subiyakto, B., Jumriani, J., Aslamiah, A., \& Afrina, A. 2019).

Dengan keadaan isu yang terus berkembang mengenai kasus penyebaran Covid 19 dikalangan masyarakat yang semakin melonjak, sedangkan bisa dikatakan sudah berbulan-bulan lamanya kasus ini terjadi, dan penerapan pada instansi pendidikan mengenai pembelajaran yang dilakukan daring, menimbulkan tanda tanya dikalangan masyarakat, apakah sistem seperi ini akan terus berlanjut. Pemerintah tidak bisa diam terkait kasus Covid 19 yang tidak memperoleh titik terang sampai kapan akan berakhir, dari sistem ekonomi yang sangat amat menurun, dan sistem pembelajaran juga banyak dikeluhkan oleh masyarakat. Membuat pemerintah dengan tegas mengambil sikap mengenai keadaan New Normal, guna mengembalikan perekonomian yang semakin menurun. Seperti kita ketahui New Normal sendiri bukanlah hidup dengan keadaan normal seperti layaknya dahulu, namun segala aktivitas yang dilakukan diluar rumah bisa dilakukan dengan mengikuti aturan protokol kesehatan. Namun aktivitas untuk 
melakukan pembelajaran tatap muka harus dipikikan matang-matang, mengingat banyak anak-anak juga dalam ranah pendidikan.

Terkait pendidikan, menteri pendidikan mengambil keputusan bahwa pendidikan bisa dilakukan penerapan New Normal jika daerah yang menerapkan sudah masuk dalam Zona hijau, tidak hanya sembarang zona hijau, semua aturan juga dipikirkan matang-matang mengikuti aturan protokol kesehatan, mengingat dalam pendidikan banyaknya interaksi yang dilakukan termasuk peserta didik, hal tersebut juga tergantung wewenang sekolah tersebut, apakah akan menerapkan tatap muka atau tidak, artinya daerah yang sudah zona hijau mempunyai wewenang untuk melakukan sistem pembelajaran apa yang diinginkan, namun daerah yang belum terdapat zona hijau dilarang atau tidak diberkenankan untuk melakukan sistem pembelajaran New normal yaitu tatap muka. Artinya daerah yang bukan termasuk zona hijau mau tidak mau harus mengikuti aturan yang diterapkan seperti saat pendemi, dilakukan dengan sistem (daring).

Efek keras dari pendemi Covid 19, Sumber pembelajaran yang sampai saat ini hanya berfokus pada pengembangan aspek kognitif sehingga seolah acuh terhadap aspek afektif atau perubahan sikap bagi peserta didik, dengan pendemi Covid ini semua aspek harus saling berhubungan dan menjadikan adanya feedback dari pembelajaran dalam sistem (daring) yang diharapkan mampu menyamai ataupun bisa melebihi kualitas sistem pembelajaran tatap muka. (Noerkhalishah, N., Abbas, E. W., \& Permatasari, M. A. 2020).

Meskipun pembelajaran yang menggunakan fasilitas teknologi internet dengan berbagai pendukung elektronik lainnya dengan sistem (daring) yang diterapkan tetap tidak akan bisa mengganti peran tenaga pendidik dalam pembelajaran. (Syaharuddin, S. 2020).

\section{SIMPULAN}

Keadaan New Normal sekarang, tidak merubah tatanan sistem yang dilakukan pendidikan dalam perubahan pola pembelajaran, hal tersebut masih 
sama dengan ruang lingkup yang terjadi yaitu masih banyak sekolah yang menggunakan sistem (daring), hanya ada beberapa sekolah yang baru ingin memulai penerapan sistem pembelajaran tatap muka, mengingat banyak hal yang harus dipertimbangkan demi keberlangsungan peserta didik, tenaga pendidik bahkan lingkungan yang berada di sekolah tersebut apakah sudah mampu menerapkan satu pikiran mengikuti segala aturan protokol kesehatan jika ingin melakukan sistem pembelajaran tatap muka. 


\section{DAFTAR PUSTAKA}

ABBAS, E. W., Hidayat Putra, M. A., \& Noor Handy, M. R. (2019). Laporan Penelitian: PEMANFAATAN EKOWISATA SUNGAI MARTAPURA KOTA BANJARMASIN SEBAGAI SUMBER BELAJAR IPS.

Hasanah, M., \& Mutiani, M. (2019). Pemahaman Wajib Belajar 12 Tahun di Sekolah Bawang Banjarmasin. Bubungan Tinggi: Jurnal Pengabdian Masyarakat, 1(1), 15-20. Rahman, A. M., Mutiani, M., \& Putra, M.

A. H. (2019).

Mutiani, M. (2019). SOCIAL CAPITAL DAN TANTANGAN ABAD 21: Kontrubusi

Mutiani, M., Subiyakto, B., Jumriani, J., Aslamiah, A., \& Afrina, A. (2019). Laporan Penelitian: Relevansi Modal Sosial Dalam Pembelajaran IPS (Studi Kasus Dalam Sistem Zonasi Di Smp Negeri Kota Banjarmasin).

Mutiani, M., WARMANSYAH ABBAS, E. R. S. I. S., Syaharuddin, S., \& Susanto, H. (2019). Penerapan Transcript Based Lesson Analyses (TBLA) Sebagai Upaya Peningkatan Pembelajaran Sejarah Di Sma Negeri 7 Banjarmasin.

Nasih, M., Abbas, E. W., \& Syaharuddin, S. (2019). NILAI-NILAI HAUL GURU SEKUMPUL SEBAGAI SUMBER BELAJAR IPS. Jurnal Socius, 8(2).

Noerkhalishah, N., Abbas, E. W., \& Permatasari, M. A. (2020). The Utilization of Tourism Education Packages in Amanah Borneo Park as a Learning Resources on Social Studies. The Innovation of Social Studies Journal, 1(2), 158-168.

Pendidikan IPS dan Eksplorasi Nilai Sosial melalui Biografi KH Zainal Ilmi. SOCIAL CAPITAL DAN TANTANGAN ABAD 21: Kontrubusi Pendidikan IPS dan Eksplorasi Nilai Sosial melalui Biografi KH Zainal Ilmi.

Rahman, A. M., Mutiani, M., \& Putra, M. A. H. (2019). Pengaruh kompetensi pedagogik dosen terhadap motivasi belajar mahasiswa pendidikan IPS. Jurnal Darussalam: Jurnal Pendidikan, Komunikasi dan Pemikiran Hukum Islam, 10(2), 375-387.

Subiyakto, B., \& Mutiani, M. (2019). Internalisasi nilai pendidikan melalui aktivitas masyarakat sebagai sumber belajar ilmu pengetahuan sosial. Khazanah: Jurnal Studi Islam dan Humaniora, 17(1), 137-166.

Subiyakto, B., Mutiani, M., \& Hidayat Putra, M. A. (2019). Laporan Penelitian: Pergeseran Makna Klotok Bagi Masyarakat di Aliran Sungai Martapura.

Syaharuddin, S. (2020). Menimbang Peran Teknologi dan Guru dalam Pembelajaran di Era COVID-19. Menimbang Peran Teknologi dan Guru dalam Pembelajaran di Era COVID-19. 
Syaharuddin, S., \& Mutiani, M. (2020). STRATEGI PEMBELAJARAN IPS: Konsep dan Aplikasi.

Wahyuningsih, S., Abbas, E. W., \& Mutiani, M. (2020). Implementation of Leadership Value of Rudy Resnawan as a Learning Resources on Social Studies. The Innovation of Social Studies Journal, 1(2), 169-177. 